\title{
Effectiveness of the Use of iPads to Enhance Communication and Learning for Students with Autism: A Systematic Review
}

\author{
Ohoud Alhajeri, Jeffrey Alvin Anderson, Erna Alant \\ Indiana University, Bloomington
}

\begin{abstract}
This systematic review of the literature investigated the use of iPads in the classroom to facilitate communication between teachers and students with autism, including those who require augmentative and alternative communication $(A A C)$. The primary intention of this review was to identify and inform evidencebased practices in the use of iPad-based instruction in one-on-one and group interventions in schools. The review included 14 studies published between 2011 and 2015, covering two domains: communication and academic engagement skill development. The 14 studies included a total of 40 participants, ranging from 3 to 17 years of age and having a diagnosis of autism. Results of this review were largely supportive, indicating the usefulness of iPads as an effective communication and educational tool for teaching requesting skills and enhancing academic engagement in both literacy and math. Implications and suggestions for future research were addressed.
\end{abstract}

\section{Introduction}

Autism Spectrum Disorder (ASD) is a neurodevelopmental disorder of brain development that is identifiable in early childhood, affecting communication, social interactions, sensory systems, and can include repetitive and restrictive behaviors, interests, and activities [1]. Many students with autism have little or no functional speech [19] and hence experience significant communication difficulties in interacting with others [20]. Students with autism can also have difficulty learning literacy and math skills due to corresponding language impairments [15]. The potential for iPads to assist teachers to expand the communication and social skills of students with autism is promising [8]. In addition, using iPads can promote language and literacy development [16] and increase academic engagement and participation [11, 13]. This systematic review of the literature investigated the use of iPads in schools as a potentially effective educational tool to overcome communication challenges between teachers and students with autism in one-on-one and group interventions within the classroom setting. A secondary aim was to identify gaps in existing research as a basis to encourage future research. Research questions included: 1) How are teachers using iPads to promote communication competence? 2) How are teachers using iPads to enhance academic engagement? 3) What is the quality of research designs that have been used to study communication competence and academic engagement using iPads?

\section{Method}

First, a systematic search of the literature was conducted to identify empirical studies that examined the use of iPad interventions for students with autism between the ages of three and seventeen in the classroom context. Identified studies focused on promoting communication skills and enhancing academic engagement. For the purposes of this review, communication skills were defined as observed dependent variables related to communicative responses including a three-step communication sequence: initiating requests, responding to questions, and making social comments. Academic engagement skills were defined as observed dependent variables related to increase independent task completion and correct unprompted academic responding.

\subsection{Search strategy}

Google Scholar, I.U. Search, ERIC, and EBSCO electronic databases were used to search the terms (iPad) and (Autism) and (Communication) and (Academic learning). The research was limited to English-language and peer-reviewed journals. A total of 32 studies 
published between January 2011 and March 2015 were identified from the initial search strategy.

\subsection{Inclusion criteria}

Included studies focused on the use of iPads in a classroom setting and to be included in this review, the iPad-based intervention had to have been used with students or a student with a diagnosed autism spectrum disorder, between PK and 12 grades. Studies were excluded if the target student had a diagnosis other than ASD such as cerebral palsy, challenging behaviors, or significant developmental delays (SDD). Further, this review included only single-subject experimental studies and only if they met minimum requirements based on the methodological quality indicators for identifying promising approaches for individuals with language impairments [5]. These included: (a) description of participants and settings, (b) dependent variable, (c) independent variable, (d) baseline, (e) experimental control/internal validity, (f) external validity, and (g) social validity. Three studies that did not utilize singlesubject designs were excluded. Seven studies that did not report empirical data about the effects of the use of iPads such as review articles, meta-analyses, and reports were also excluded. Five studies that focused on comparisons between using iPads and other low-tech devices likewise were excluded. Independent variable was an iPad. Finally, studies that did not contain communication or academic learning were excluded.

\subsection{Data extraction}

Of the 32 studies that were published between 2011 and 2015 and identified from the initial search strategy, 14 studies met the inclusion criteria, including seven studies that included AAC users. These 14 studies were then summarized in terms of (a) description of participants, (b) skills taught using an iPad and application(s), (c) dependent variable(s), (d) results (effectiveness of using iPads), and (e) quality of evidence rating. Certainty of evidence was assessed using the Council of Exceptional Children methodological quality indicators for single subject designs [5], which include (a) description of participants and settings, (b) dependent variable, (c) independent variable, (d) baseline, (e) experimental control/internal validity, (f) external validity, and (g) social validity. The methodological indicators in terms of 22 items per study (see Table 1) were summarized [12]. According to this rating scale, 66 points are possible. For this review, studies that achieved 59 points or higher (greater than 90\%) were considered as providing conclusive evidence, while studies less than 59 were considered inconclusive. Studies were then coded as eleven conclusive studies and four inconclusive studies, depending on these ratings of methodological quality.

\subsection{Inter-rater agreement}

To examine the methodological quality indicators for each of the 32 studies initially identified, each study was coded (see Table 1). To ensure the accuracy of study characteristics and methodological indicators, included studies were next independently checked by a second rater using the checklist in Table 1 . The 22 items per study that were coded resulted in 308 total items on which there could be disagreement. Initial agreement occurred for 253 items (82\%) and final agreement, after discussion, occurred on $100 \%$ of items. As shown in Table 2, the majority of studies reported positive outcomes, with $78.6 \%$ meeting the quality standards to be rated as conclusive evidence.

\section{Results}

Table 2 summarizes the 14 studies that were ultimately included in this review. These studies were then coded according to: (a) description of participants, (b) skills taught using iPads and application(s) (c) dependent variable(s), (d) results (i.e., effectiveness of using iPads), and (e) our rating of the quality of evidence rating.

\subsection{Description of study participants}

In total, the studies included 40 students, 6 females and 34 males, who ranged from 3 to 17 years of age. All had a diagnosis of autism. One study in the review included one participant with autism and a second participant with a developmental delay [8]. One study included three participants with autism and moderate cognitive disabilities [20]. One study included two participants with autism, who had been diagnosed with Asperger syndrome (AS) and attention deficit hyperactivity disorder (ADHD) [7] and one participant with AS only [11]. Two studies included three participants with autism 
and a pervasive developmental disorder not otherwise specified [10, 11]. Two studies included three participants with autism and mild and moderate intellectual disabilities [4, 18]. Two studies included eight participants with autism, who exhibited moderate to severe developmental delays in communication, socialization, and behavior $[13,16]$.

\subsection{Skills taught using iPad and application(s)}

This review focused on using iPads to teach two targeted skills. First, for communication skills, four studies included an iPad-based speech-generating device to teach students with autism requesting skills, such as requesting the continuation of toy play [14], or teaching threestep communication sequences $[8,17,20]$. Three studies used a communication application called Proloquo2Go [8, 14, 17] and one study used a SonoFlex application [20]. Second, for teaching academic skills, three studies focused on math skills, such as numeracy [6], price comparison by using video modeling on an iPad [18], or improving math performance and increasing independent task completion through different applications such as a basic math skill app and Matching Game - My First Numbers app [13].

Eight studies focused on teaching literacy skills. One study using video modeling via an iPad to check the spelling of words [7]. Another literacy skill is to promote language development and to teach early literacy skills via shared stories by using an iPad2 with systematic instruction and GoTalk Now app [15]. Two studies used an iPad with Proloquo2Go to teach symbol discrimination [9] and picture and word matching [16].

Finally, three studies focused on teaching academic engagement skills in terms of increasing academic responding by using an iPad with video-self modeling [4], and increasing play dialogue (PD) by using an iPad with Keynote application [10]. In addition, [11] defined academic engagement as "looking at the assignment, responding to questions verbally or physically (by writing, typing, or selecting on a computer) or engaging in demand-related conversation" (p. 512). These authors used iPads with the WritePad and Little Matchups applications.

\subsection{Dependent variable(s)}

Interventions specifically targeting iPad dependent variables were purposefully sampled for this review. The most common iPad data assessed included enhanced communication skills, such as teaching requesting skills, and engagement in literacy and math for academic purposes. The most common communication skills included requesting skills, such as independent requests [8, 20], independent vocal requests [8], general requests and specific requests [17]. A second requesting skill was responses such as reaching appropriately for a toy [14], striking trainer in response to being offered a toy [14], frequency of vocal responses [8], correct responses [8, 14, 17, 20], and thank you responses [17]. The third requesting skill was comments, specifically thank you [20].

Using iPads to engage literacy and math for academic purposes was the next most common dependent variable. In the category of math, the first differentiation of dependent variables was to identify, write, and comprehend the quantity of numbers from $1-7$ [6], and independent comparisons of grocery item shopping [18], independently completing math tasks on assessments [13], the presence of noncompliant behaviors during assessment [13], and, finally, the level of teacher prompting during the assessment [13]. The second category related to engagement in literacy and math was literacy regarding checking spelling [7], the number of play dialogue utterances [10], independent correct responses on story analysis [15], unprompted correct responses to listening and comprehension questions [15]. Enhanced communication skills were also examined by studies targeting AAC users [8, 9, 16, 14, 15, 17, 20].

Other dependent variables examined included general academic engagement such as the frequency of correct unprompted academic responses [4], and the percentage of intervals with appropriate academic engagement while using traditional materials during iPad sessions [11].

\subsection{Results and methodological quality}

Results from studies that included communication skills were overall positive, with only one study [8] reporting no effect for one participant. This suggests that the use of an iPad as a communication tool is an effective intervention for preschool and elementary aged 
students with autism; in total, 10 of 11 participants benefited from the intervention. Concurrently, the results of the studies focused on academic skills were overwhelmingly positive with just two studies [9, 10] reporting no effect for one participant in each of the two studies. This suggests that the use of iPads as educational and instructional tools for engagement in literacy and math for academic purposes appears to provide effective interventions for children and adolescents with autism; in total, 27 of 29 participants benefited from the intervention. In terms of design quality, 11 of the 14 studies met at least $90 \%$ of the methodological quality indicators adapted from [5]. This suggests a relatively high methodological rigor for this set of studies. The most common reason that studies were rated as inconclusive was the lack of evidence to directly measure fidelity or social validity.

\section{Discussion}

Educators will encounter various challenges during the teaching-learning process, including student-teaching communication, providing effective academic skill instruction, and developing the skills and resources to make use of the best available technology. iPads appear to offer an important technological platform for students with autism.

This systematic review examined the effectiveness of the use of iPads in the both special and general education classrooms with a specific focus on iPads as a communication and educational tool to enhance engagement for students with autism, including those who require augmentative and alternative communication (AAC). In the 14 studies reviewed in this paper, of the 40 study participants, all who were students diagnosed with autism, 20 students also were using AAC devices. Moreover, our findings were largely positive, suggesting that iPad use appears to be evidence-based and therefore effective for enhancing communication and engagement in literacy and math, at least for students with autism. These results also suggest that students with autism can be taught to use mobile technology devices such as iPads for a variety of purposes and specifically for enhancement of communication and academic engagement skills. With regard to communication skills, the use of an iPad-based intervention also appears to be effective for many students with autism and who require AAC. For example, using an iPad-based speech-generating device (SGD) was shown to help students effectively request continuation of toy play [14]. Likewise, using an iPad with Proloquo2Go app may offer an effective intervention for requesting preferred items [8] and performing request and social communication sequence [17]. Another effective communication intervention appears to be the use of iPads with the SonoFlex app to increase communication skills in class activities [20].

In terms of engagement in literacy and math for academic purposes, using an iPad with video self-modeling appears to be effective. Across the studies reviewed, participants made gains: increasing the frequency of correct unprompted academic responses [4], completing comparison tasks [18], and/or checking the spelling of words [7]. In one study, two students reached the 76$100 \%$ correct level on the task analysis when the video modeling intervention was delivered via an iPad. Using iPad-based video modeling also may provide an effective intervention to increase students' abilities to identify and write numbers from one to seven [6]. Using an iPad with Proloquo2Go app as a speech-generating device helped students to discriminate between picture symbols [9] and increase correct matching [16]. iPad interventions also appeared to effectively increased levels of play dialogue when using an iPad play story [10]. The use of an iPad with systematic instruction and GoTalk Now app helped students to increase the number of independent correct responses on a shared story task analysis [15] and also to increase learning and independent levels [13]. Finally, using the iPad with apps increased academic engagement and reduced challenging behavior [11]. Taken together, these studies suggest iPads can provide effective communication and instructional tools in the classroom, therefore, adding evidence to the practices of using of iPad-based instruction in one-on-one and group settings for students with autism.

\section{Limitations and implications for future research}

Perhaps the primary limitation of this systematic literature review is timing. We speculate that the number of studies about iPad use will increase dramatically in the coming years and as you read this, it is very likely additional studies, not included in our review, have already been published. Similarly, like any review of the literature, these findings are only as 
complete as were our search techniques. We feel the steps used to gather data for this study (i.e., published research articles) were painstaking and comprehensive. Still it is always possible that something important was missed. Finally, all of the studies included in this review indicated mostly positive outcomes, in terms of enhancing communication skills and engagement in literacy and math for academic purposes. However, longer-term impact of the use of iPads for those purposes has not been studied. This is not surprising given that iPads have only been in existence since 2008. Still, we note that little is known about the maintenance of the skill development reported in these studies. These data encompasses only seven years of use and as previously stated the most informative research is likely still on the horizon. Several additional limitations for this review also are relevant. For example, the impact of iPads for enhancing communication skills for students aged three to ten with autism ignores the importance of developing meaning between teachers and students. The majority of academic articles are on literacy use with Prolou2Go as a communication application.

In light of these limitations, this study adds valuable information to the field and the classroom. We end with several suggestions for next steps. First, researchers and practitioners should consider the value of using iPad applications across curricular academic endeavors with students who have autism. While still emerging, the evidence appears to suggest these new technologies can substantially assist with teaching and learning. Second, the field will need to stay abreast of new technology. As an example from our findings, we suggest that an alternative to Prolouqo2Go communicative application might be Language Acquisition through Motor Planning (LAMP) application. Additional applications for the iPad might include the concept of using the iPad as a reinforcement tool toward the end goal of positive motivation as a reward system in the academic setting. However, translating research evidence to classroom practice has remained a formidable objective for the entire history of educational research and the speed of technological advances in the $21^{\text {st }}$ century is likely to seriously increase the research-topractice gap. A final positive application of using iPads in both special education and general education classrooms would be that of motivation for teachers to utilize AAC applications toward the goal of inclusion. Indeed, we speculate that the possibilities are vast. However, it was evident that iPad interventions were only implemented to requesting skills for students with autism and therefore, we call on researchers to examine approaches for teaching other communication skills.

\section{Conclusion}

This systematic review of the literature investigated the use of iPads in classrooms to facilitate communication between teachers and students with autism. Results indicated that the small but growing research base suggests iPads can provide an effective communication and educational tool for teaching requesting skills and enhancing academic engagement.

The results of this review are help teachers understand: a) how to conduct similar systematic reviews to both understand how to synthesize research literature and apply results to their own settings; b) how iPads can be effectively used to enhance communication and engagement in literacy and math for students with autism; and c) ways in which students with autism can be taught to use mobile technology devices such as iPads for a variety of purposes and specifically for enhancement of communication and academic engagement skills.

\section{Acknowledgments}

The authors wish to thank some doctoral students in special education program in School of Education at Indiana University for their assistance with establishing inter-rater reliability for this study. 
Table 1. Methodological Quality Indicators

\begin{tabular}{|c|c|c|c|}
\hline $\begin{array}{c}\text { Rational \& Lit } \\
\text { Review }\end{array}$ & 1 & & \\
\hline $\begin{array}{l}\text { Compelling case for } \\
\text { research }\end{array}$ & Inadequate & \multicolumn{2}{|c|}{ Adequate lit review, appropriate rationale } \\
\hline Research questions & Inappropriate & \multicolumn{2}{|c|}{ Appropriate and operationalized questions } \\
\hline $\begin{array}{l}\text { Participants \& } \\
\quad \text { Setting }\end{array}$ & 1 & 2 & 3 \\
\hline $\begin{array}{l}\text { Participant } \\
\text { Characteristics }\end{array}$ & Limited detail, not replicable & $\begin{array}{l}\text { Some detail, limited } \\
\text { replicability }\end{array}$ & Ample detail, replicable \\
\hline $\begin{array}{l}\text { Process for selecting } \\
\text { participants }\end{array}$ & Limited detail, not replicable & $\begin{array}{l}\text { Some detail, limited } \\
\text { replicability }\end{array}$ & Ample detail, replicable \\
\hline Setting Description & $\begin{array}{l}\text { Limited description, not } \\
\text { replicable }\end{array}$ & $\begin{array}{l}\text { Some description, limited } \\
\text { replicability }\end{array}$ & $\begin{array}{l}\text { Detailed description, } \\
\text { replicable }\end{array}$ \\
\hline Dependent Variable & 1 & 2 & 3 \\
\hline Description of DV & $\begin{array}{l}\text { Limited description, poorly } \\
\text { operationalized, not replicable }\end{array}$ & $\begin{array}{l}\text { Some description, poorly } \\
\text { operationalized, limited } \\
\text { replicability }\end{array}$ & $\begin{array}{l}\text { Detailed description, } \\
\text { operationalized, replicable }\end{array}$ \\
\hline $\begin{array}{l}\text { Measurement } \\
\text { Procedures }\end{array}$ & $\begin{array}{l}\text { Limited description, not } \\
\text { replicable }\end{array}$ & $\begin{array}{l}\text { Some description, limited } \\
\text { replicability }\end{array}$ & $\begin{array}{l}\text { Detailed description, } \\
\text { replicable procedure }\end{array}$ \\
\hline $\begin{array}{l}\text { Repeated } \\
\text { Measurement }\end{array}$ & $\begin{array}{l}\text { Insufficient data collected, } \\
\text { inconsistent measurement }\end{array}$ & $\begin{array}{l}\text { Consistent measurement, } \\
\text { insufficient data collected }\end{array}$ & $\begin{array}{l}\text { Consistent measurement, } \\
\text { sufficient data collected }\end{array}$ \\
\hline $\begin{array}{l}\text { DV Socially } \\
\text { Important? }\end{array}$ & Not socially important & Limited importance & Socially important \\
\hline $\begin{array}{l}\text { Interobserver } \\
\text { Agreement }\end{array}$ & Not reported & Below $80 \%$ & Above $80 \%$ \\
\hline $\begin{array}{l}\text { Independent } \\
\text { Variable }\end{array}$ & 1 & 2 & 3 \\
\hline Description of IV & $\begin{array}{l}\text { Limited description, poorly } \\
\text { operationalized }\end{array}$ & $\begin{array}{l}\text { Some description, poorly } \\
\text { operationalized }\end{array}$ & $\begin{array}{l}\text { Detailed description, } \\
\text { operationalized }\end{array}$ \\
\hline $\begin{array}{l}\text { IV manipulation and } \\
\text { control }\end{array}$ & $\begin{array}{l}\text { Limited descript., not } \\
\text { controlled, not replicable }\end{array}$ & $\begin{array}{l}\text { Some descript. \& control } \\
\text { limited replicability }\end{array}$ & $\begin{array}{l}\text { Detailed descript., } \\
\text { controlled, replicable }\end{array}$ \\
\hline Fidelity & Not measured & Measured Indirectly & Measured Directly \\
\hline
\end{tabular}


Table 1. Methodological Quality Indicators (continued)

\begin{tabular}{|c|c|c|c|}
\hline Graphical Analysis & 1 & 2 & 3 \\
\hline $\begin{array}{l}\text { Requirements for data } \\
\text { points }\end{array}$ & $\begin{array}{l}<3 \text { data points in } \\
\text { BL\&INTV }\end{array}$ & & $>3$ data points in BL \& INTV \\
\hline $\begin{array}{l}\text { Baseline condition } \\
\text { description }\end{array}$ & $\begin{array}{l}\text { Limited description, not } \\
\text { replicable }\end{array}$ & $\begin{array}{l}\text { Some description, limited } \\
\text { replicability }\end{array}$ & $\begin{array}{l}\text { Detailed description, } \\
\text { replicable }\end{array}$ \\
\hline Trends in data & Trend in BL\&INTV & Trend in INTV & No Trend observed \\
\hline $\begin{array}{l}\text { Internal } \\
\text { Validity }\end{array}$ & 1 & 2 & 3 \\
\hline $\begin{array}{l}\text { Threats to internal } \\
\text { validity? }\end{array}$ & $\begin{array}{l}\text { No controls for rival } \\
\text { hypotheses }\end{array}$ & $\begin{array}{l}\text { Some controls for rival } \\
\text { hypotheses }\end{array}$ & $\begin{array}{l}\text { Controlled for rival } \\
\text { hypotheses }\end{array}$ \\
\hline Functional relationship & No effect & Some effect & Significant effect \\
\hline $\begin{array}{l}\text { External/ Social } \\
\text { Validity }\end{array}$ & 1 & 2 & 3 \\
\hline Replication of Results & No replication & $\begin{array}{l}\text { Across participants OR } \\
\text { settings/partners }\end{array}$ & $\begin{array}{l}\text { Across participants \& } \\
\text { settings/partners }\end{array}$ \\
\hline Practicality & Limited practicality & Somewhat practical & Practical \\
\hline Social validity? & Not Assessed & Indirectly assessed & Directly assessed \\
\hline $\begin{array}{l}\text { Change socially } \\
\text { significant? }\end{array}$ & No change & $\begin{array}{l}\text { Positive change, not socially } \\
\text { significant }\end{array}$ & $\begin{array}{l}\text { Socially significant positive } \\
\text { change }\end{array}$ \\
\hline
\end{tabular}


Table 2. Summary of Studies Involving iPads

\begin{tabular}{|c|c|c|c|c|c|}
\hline Study & $\begin{array}{l}\text { Description of } \\
\text { participants }\end{array}$ & $\begin{array}{c}\text { Skills taught in using iPad } \\
\text { and } \\
\text { Application(s) }\end{array}$ & Dependent Variables & $\begin{array}{l}\text { Effectiveness of using } \\
\text { iPads }\end{array}$ & $\begin{array}{l}\text { Quality of Evidence Rating } \\
\text { (66 max })\end{array}$ \\
\hline $\begin{array}{l}\text { Communication skills } \\
\text { Sigafoos et al. (2013) }\end{array}$ & $\begin{array}{l}\text { Two brothers: } \\
5 \text { years, male with ASD } \\
4 \text { years, male with ASD }\end{array}$ & $\begin{array}{l}\text { Request the continuation } \\
\text { of toy play } \\
\text { Proloquo2Go }\end{array}$ & $\begin{array}{l}\text { 1) Correct requesting as } \\
\text { touching the TOY PLAY } \\
\text { symbol without any } \\
\text { physical guidance and } \\
\text { within } 10 \text { s of the child's } \\
\text { toy play } \\
\text { 2) Reaching as the child } \\
\text { move one or both hands } \\
\text { toward the toy being held } \\
\text { by the trainer and/or } \\
\text { touching the toy within } 10 \\
\text { s from the start of the } \\
\text { interruption } \\
\text { 3) Hitting, any time during } \\
\text { the } 10 \text {-s interruption the } \\
\text { child hit the trainer with a } \\
\text { closed or open hand }\end{array}$ & $\begin{array}{l}\text { Using an iPad-based } \\
\text { speech-generating device } \\
\text { (SGD) helps students to } \\
\text { request effectively the } \\
\text { continuation of toy play }\end{array}$ & Conclusive evidence 59 \\
\hline King et al. (2014) & $\begin{array}{l}4 \text { years, female with ASD, } \\
1 \text { word utterances } \\
5 \text { years, female with ASD, } \\
\text { idiosyncratic speech } \\
3 \text { years, male with ASD } \\
\text { and developmental delay, } \\
\text { only made sounds }\end{array}$ & $\begin{array}{l}\text { Teach requesting skills } \\
\text { Proloquo2Go }\end{array}$ & $\begin{array}{l}\text { 1) The percent independent } \\
\text { requesting across phases } \\
\text { 2) The frequency of vocal } \\
\text { requests across phases }\end{array}$ & $\begin{array}{l}\text { Using the iPad with } \\
\text { Proloquo2Go app is an } \\
\text { effective intervention to } \\
\text { request preferred items }\end{array}$ & $\begin{array}{l}\text { Positive for } 3 \text { of } 4 \text {. } \\
\text { Inconclusive evidence } 57\end{array}$ \\
\hline
\end{tabular}


Table 2. Summary of Studies Involving iPads (continued)

\begin{tabular}{|c|c|c|c|c|c|}
\hline Study & $\begin{array}{l}\text { Description of } \\
\text { participants }\end{array}$ & $\begin{array}{c}\text { Skills taught in using iPad } \\
\text { and } \\
\text { Application(s) }\end{array}$ & Dependent Variables & $\begin{array}{c}\text { Effectiveness of using } \\
\text { iPads }\end{array}$ & $\begin{array}{l}\text { Quality of Evidence Rating } \\
\text { (66 max) }\end{array}$ \\
\hline Waddington et al. (2014) & $\begin{array}{l}7 \text { years, male with ASD } \\
8 \text { years, male with ASD } \\
10 \text { years, male with ASD }\end{array}$ & $\begin{array}{l}\text { Teach three-step } \\
\text { communication sequence } \\
\text { Proloquo2Go }\end{array}$ & $\begin{array}{l}\text { Correct responses for the } \\
\text { three steps: } \\
\text { 1) General toy request } \\
\text { 2) Specific toy request } \\
\text { 3) Thank-you response }\end{array}$ & $\begin{array}{l}\text { Using the iPad with } \\
\text { Proloquo2Go app } \\
\text { improves effectively to } \\
\text { perform requesting and } \\
\text { social communication } \\
\text { sequence }\end{array}$ & Conclusive evidence 60 \\
\hline Xin and Leonard (2014) & $\begin{array}{l}10 \text { years, female with ASD } \\
\text { and a moderate cognitive } \\
\text { disability, non-verbal } \\
10 \text { years, male with ASD } \\
\text { and a moderate cognitive } \\
\text { disability, non-verbal } \\
10 \text { years, male with ASD } \\
\text { and a moderate cognitive }\end{array}$ & $\begin{array}{l}\text { Teach communication } \\
\text { skills during class and } \\
\text { recess settings } \\
\text { SonoFlex }\end{array}$ & $\begin{array}{l}\text { Median scores of each } \\
\text { student's use of the iPad to } \\
\text { 1) Make requests } \\
\text { 2) Make responses } \\
\text { 3) Make comments }\end{array}$ & $\begin{array}{l}\text { Using the iPad with } \\
\text { SonoFlex app effectively } \\
\text { increase communication } \\
\text { skills in class activities }\end{array}$ & Conclusive evidence 60 \\
\hline \multicolumn{6}{|l|}{ Academic skills } \\
\hline Hart and Whalon (2012) & $\begin{array}{l}16 \text { years, male with autism } \\
\text { and moderate intellectual } \\
\text { disability }\end{array}$ & $\begin{array}{l}\text { Increase academic } \\
\text { responding } \\
\text { Video self-modeling } \\
\text { (VSM) }\end{array}$ & $\begin{array}{l}\text { Frequency of correct } \\
\text { unprompted academic } \\
\text { responding }\end{array}$ & $\begin{array}{l}\text { Using iPad with video self- } \\
\text { modeling is effective to } \\
\text { increase the frequency of } \\
\text { correct unprompted } \\
\text { academic responding }\end{array}$ & Conclusive evidence 62 \\
\hline
\end{tabular}


Table 2. Summary of Studies Involving iPads (continued)

\begin{tabular}{|c|c|c|c|c|c|}
\hline Study & $\begin{array}{l}\text { Description of } \\
\text { participants }\end{array}$ & $\begin{array}{c}\text { Skills taught in using iPad } \\
\text { and } \\
\text { Application(s) }\end{array}$ & Dependent Variables & $\begin{array}{c}\text { Effectiveness of using } \\
\text { iPads }\end{array}$ & $\begin{array}{l}\text { Quality of Evidence Rating } \\
\text { (66 max) }\end{array}$ \\
\hline $\begin{array}{l}\text { Jowett, Moore, and } \\
\text { Anderson (2012) }\end{array}$ & $\begin{array}{l}5 \text { years } 6 \text { months, male } \\
\text { with ASD }\end{array}$ & $\begin{array}{l}\text { Teach numeracy skills } \\
\text { Video modeling (VM) } \\
\text { package via an iPad }\end{array}$ & $\begin{array}{l}\text { Indicators of ability to } \\
\text { identify, write, and } \\
\text { comprehend the quantity } \\
\text { of numbers from } 1-7\end{array}$ & $\begin{array}{l}\text { Using an iPad-based video } \\
\text { modeling is an effective } \\
\text { intervention in increasing } \\
\text { the student's ability to } \\
\text { identify and write numbers } \\
\text { from } 1-7\end{array}$ & Conclusive evidence 63 \\
\hline $\begin{array}{l}\text { Kagohara, Sigafoos, } \\
\text { Achmadi, O'Reilly, and } \\
\text { Lancioni (2012) }\end{array}$ & $\begin{array}{l}12 \text { years } 1 \text { month, male } \\
\text { with ASD, diagnosed } \\
\text { Asperger syndrome (AS) } \\
\text { and attention hyper activity } \\
\text { disorder (ADHD) } \\
10 \text { years } 7 \text { months, female } \\
\text { with ASD, diagnosed (AS) } \\
\text { and (ADHD) }\end{array}$ & $\begin{array}{l}\text { Check the spelling of } \\
\text { words } \\
\text { Video modeling via an } \\
\text { iPad }\end{array}$ & $\begin{array}{l}\text { The number of steps in the } \\
\text { task analysis that were } \\
\text { performed correctly during } \\
\text { each session }\end{array}$ & $\begin{array}{l}\text { Using an iPad-based video } \\
\text { modeling is an effective } \\
\text { intervention in teaching the } \\
\text { two students with ASD to } \\
\text { check the spelling of words } \\
\text { The two students reached } \\
\text { the } 76-100 \% \text { correct level } \\
\text { on the task analysis when } \\
\text { delivered the video } \\
\text { modeling intervention via } \\
\text { an iPad. }\end{array}$ & Conclusive evidence 60 \\
\hline $\begin{array}{l}\text { Murdock, Ganz, and } \\
\text { Crittendon (2013) }\end{array}$ & $\begin{array}{l}4 \text { years, male with ASD } \\
\text { and PDD-NOS } \\
4 \text { years } 8 \text { months, male } \\
\text { with ASD } \\
4 \text { years } 5 \text { months, male } \\
\text { with ASD and PDD-NOS } \\
4 \text { years } 3 \text { months, male } \\
\text { with ASD }\end{array}$ & $\begin{array}{l}\text { Increase play dialogue } \\
\text { (PD) } \\
\text { Keynote app }\end{array}$ & $\begin{array}{l}\text { The number of PD } \\
\text { utterances }\end{array}$ & $\begin{array}{l}\text { Using an iPad play story is } \\
\text { an effective intervention to } \\
\text { increase levels of play } \\
\text { dialogue }\end{array}$ & $\begin{array}{l}\text { Positive for } 3 \text { of } 4 \text {. } \\
\text { Inconclusive evidence } 58\end{array}$ \\
\hline
\end{tabular}


Table 2. Summary of Studies Involving iPads (continued)

\begin{tabular}{|c|c|c|c|c|c|}
\hline Study & $\begin{array}{l}\text { Description of } \\
\text { participants }\end{array}$ & $\begin{array}{c}\text { Skills taught in using iPad } \\
\text { and } \\
\text { Application(s) }\end{array}$ & Dependent Variables & $\begin{array}{c}\text { Effectiveness of using } \\
\text { iPads }\end{array}$ & $\begin{array}{l}\text { Quality of Evidence Rating } \\
\text { (66 max) }\end{array}$ \\
\hline $\begin{array}{l}\text { Neely, Rispoli, Camargo, } \\
\text { Davis, and Boles (2013) }\end{array}$ & $\begin{array}{l}7 \text { years, male with } \\
\text { Asperger's Disorder } \\
3 \text { years, male with a } \\
\text { pervasive developmental } \\
\text { disorder not otherwise } \\
\text { specified (PDD-NOS) }\end{array}$ & $\begin{array}{l}\text { Observe challenging } \\
\text { behavior: } \\
\text { (a) verbal protesting, (b) } \\
\text { aggression, and } \\
\text { (c) demand avoidance } \\
\text { Observe academic } \\
\text { engagement: } \\
\text { (a) looking at the } \\
\text { assignment, (b) responding } \\
\text { to questions verbally or } \\
\text { physically (by writing, } \\
\text { typing, or selecting on a } \\
\text { computer) or (c) engaging } \\
\text { in demand-related } \\
\text { conversation. } \\
\text { WritePad app } \\
\text { Little Matchups app }\end{array}$ & $\begin{array}{l}\text { 1) Percentage of intervals } \\
\text { with challenging behavior } \\
\text { during single-function } \\
\text { functional analysis } \\
\text { 2) Percentage of intervals } \\
\text { with challenging behavior } \\
\text { during traditional materials } \\
\text { and iPad sessions } \\
\text { 3) Percentage of intervals } \\
\text { with academic engagement } \\
\text { during traditional materials } \\
\text { and iPad sessions }\end{array}$ & $\begin{array}{l}\text { Using iPad with apps } \\
\text { increases academic } \\
\text { engagement and reduces } \\
\text { challenging behavior }\end{array}$ & Conclusive evidence 62 \\
\hline $\begin{array}{l}\text { Lorah, Crouser, Gilroy, } \\
\text { Tencani, and Hantula } \\
\text { (2014) }\end{array}$ & $\begin{array}{l}5 \text { years } 5 \text { months, male } \\
\text { with autism } \\
4 \text { years } 3 \text { months, male } \\
\text { with autism } \\
5 \text { years, male with autism } \\
6 \text { years } 2 \text { months, male } \\
\text { with autism }\end{array}$ & $\begin{array}{l}\text { Teach symbol } \\
\text { discrimination } \\
\text { Proloquo2Go }\end{array}$ & $\begin{array}{l}\text { Rate of independent and } \\
\text { accurate requests }\end{array}$ & $\begin{array}{l}\text { Using an iPad with } \\
\text { Proloquo2Go app as a } \\
\text { speech generating device } \\
\text { helps students to } \\
\text { discriminate between } \\
\text { pictures symbols }\end{array}$ & $\begin{array}{l}\text { Positive for } 3 \text { of } 4 \text {. } \\
\text { Inconclusive evidence } 58\end{array}$ \\
\hline
\end{tabular}


Table 2. Summary of Studies Involving iPads (continued)

\begin{tabular}{|c|c|c|c|c|c|}
\hline Study & $\begin{array}{c}\text { Description of } \\
\text { participants }\end{array}$ & $\begin{array}{c}\text { Skills taught in using iPad } \\
\text { and } \\
\text { Application(s) }\end{array}$ & Dependent Variables & Effectiveness of using iPads & $\begin{array}{c}\text { Quality of Evidence } \\
\text { Rating (66 max) }\end{array}$ \\
\hline $\begin{array}{l}\text { O'Malley, Lewis, } \\
\text { Donehower, and Stone } \\
(2014)\end{array}$ & $\begin{array}{l}\text { 11years, female with } \\
\text { autism } \\
11 \text { years, female with } \\
\text { autism } \\
11 \text { years, male with autism } \\
11 \text { years, male with autism } \\
12 \text { years, male with autism } \\
12 \text { years, male with autism } \\
13 \text { years, male with autism } \\
\text { All participants exhibit } \\
\text { moderate to severe } \\
\text { developmental delays in } \\
\text { communication, } \\
\text { socialization, and behavior }\end{array}$ & $\begin{array}{l}\text { Increase independent task } \\
\text { completion } \\
\text { Improve math performance } \\
\text { A basic math skill app } \\
\text { Matching Game - My First } \\
\text { Numbers app by } \\
\text { Grasshopper Apps }\end{array}$ & $\begin{array}{l}\text { 1) The number of } \\
\text { independently completed } \\
\text { math tasks on assessment } \\
\text { probes } \\
\text { 2) The presence of } \\
\text { noncompliant behaviors } \\
\text { 3) The level of teacher } \\
\text { prompting }\end{array}$ & $\begin{array}{l}\text { Using an iPad with math apps } \\
\text { is an effective instructional } \\
\text { tool to increase learning and } \\
\text { independent levels }\end{array}$ & Conclusive 64 \\
\hline $\begin{array}{l}\text { Spooner, Ahlgrim-Delzell, } \\
\text { Kemp-Inman, and Wood } \\
(2014)\end{array}$ & $\begin{array}{l}12 \text { years, male with autism, } \\
\text { non-verbal } \\
8 \text { years, male with autism, } \\
\text { non-verbal } \\
11 \text { years, male with autism, } \\
\text { non-verbal } \\
8 \text { years, male with autism, } \\
\text { non-verbal }\end{array}$ & $\begin{array}{l}\text { Teach early literacy skills } \\
\text { via shared stories } \\
\text { An iPad2 with systematic } \\
\text { instruction. } \\
\text { GoTalk Now app }\end{array}$ & $\begin{array}{l}\text { 1) Independent correct } \\
\text { responses on shared story } \\
\text { task analysis } \\
\text { 2) The number of correct } \\
\text { unprompted responses to } \\
\text { listening comprehension } \\
\text { questions }\end{array}$ & $\begin{array}{l}\text { Using an iPad with systematic } \\
\text { instruction and GoTalk Now } \\
\text { app helps students to increase } \\
\text { the number of independent } \\
\text { correct responses on the shared } \\
\text { story task analysis }\end{array}$ & $\begin{array}{l}\text { Conclusive evidence } \\
59\end{array}$ \\
\hline
\end{tabular}


Table 2. Summary of Studies Involving iPads (continued)

\begin{tabular}{|c|c|c|c|c|c|}
\hline Study & $\begin{array}{l}\text { Description of } \\
\text { participants }\end{array}$ & $\begin{array}{c}\text { Skills taught in using iPad } \\
\text { and } \\
\text { Application(s) }\end{array}$ & Dependent Variables & $\begin{array}{c}\text { Effectiveness of using } \\
\text { iPads }\end{array}$ & $\begin{array}{l}\text { Quality of Evidence Rating } \\
\text { (66 max })\end{array}$ \\
\hline Weng and Bouck (2014) & $\begin{array}{l}17 \text { years, male with autism } \\
\text { and moderate intellectual } \\
\text { disability } \\
15 \text { years, male with autism } \\
\text { and mild intellectual } \\
\text { disability } \\
15 \text { years, male with autism }\end{array}$ & $\begin{array}{l}\text { Teach price comparison } \\
\text { Video prompting }\end{array}$ & $\begin{array}{l}\text { The mean percent of the } \\
\text { lowest-priced grocery item } \\
\text { independently selected per } \\
\text { session for baseline, } \\
\text { treatment, and } \\
\text { generalization }\end{array}$ & $\begin{array}{l}\text { Using video prompting via } \\
\text { iPad is an effective } \\
\text { intervention for two } \\
\text { students to complete } \\
\text { comparison tasks }\end{array}$ & Conclusive evidence 62 \\
\hline van der Meer et al. (2015) & $\begin{array}{l}10 \text { years } 2 \text { months, male } \\
\text { with autism and severe } \\
\text { communication } \\
\text { impairment }\end{array}$ & $\begin{array}{l}\text { Teach picture and word } \\
\text { matching } \\
\text { Proloquo2Go }\end{array}$ & $\begin{array}{l}\text { 1) Correct responses across } \\
\text { sessions for each of four } \\
\text { matching tasks: } \\
\text { (a) picture to picture, (b) } \\
\text { word to picture, (c) picture } \\
\text { to word, (d) word to word }\end{array}$ & $\begin{array}{l}\text { Using an iPad with } \\
\text { Proloquo2Go app as a } \\
\text { speech generating device } \\
\text { helps the student to } \\
\text { increase correct matching } \\
\text { across four combinations: } \\
\text { (a) picture to picture, (b) } \\
\text { word to picture, (c) picture } \\
\text { to word, and (d) word to } \\
\text { word }\end{array}$ & Conclusive evidence 63 \\
\hline
\end{tabular}




\section{References}

[1] American Psychiatric Association. Diagnostic and statistical manual of mental disorders (5th ed.). American Psychiatric Publishing, Arlington, VA, 2013.

[2] Bouck, E., Savage, M., Meyer, N., Taber-Doughty, T., \& Hunley, M, "High-tech or low-tech? Comparing self-monitoring systems to increase task independence for students with autism", Focus On Autism And Other Developmental Disabilities, Thousand Oaks, CA, 2014, pp. 156-167.

[3] Ganz, J. B., Hong, E. R., Goodwyn, F., Kite, E., \& Gilliland, W, "Impact of PECS tablet computer app on receptive identification of pictures given a verbal stimulus", Developmental neurorehabilitation, London : Informa Healthcare, England, 2013, pp. 1-6.

[4] Hart, J. E., \& Whalon, K. J., "Using video selfmodeling via iPads to increase academic responding of an adolescent with autism spectrum disorder and intellectual disability", Education and Training in Autism and Developmental Disabilities, Division on Autism and Developmental Disabilities, USA, 2012, pp. 438-446.

[5] Horner, R. H., Carr, E. G., Halle, J., McGee, G., Odom, S., \& Wolery, M., "The use of single-subject research to identify evidence-based practice in special education", Exceptional Children, Council for Exceptional Children, Reston, VA, USA, 2005, pp. 165-179.

[6] Jowett, E. L., Moore, D. W., \& Anderson, A., "Using an iPad-based video modelling package to teach numeracy skills to a child with an autism spectrum disorder", Developmental Neurorehabilitation, London : Informa Healthcare, England, 2012, pp. 304-312.

[7] Kagohara, D. M., Sigafoos, J., Achmadi, D., O'Reilly, M., \& Lancioni, G., "Teaching Children with Autism Spectrum Disorders to Check the Spelling of Words", Research in Autism Spectrum Disorders, Elsevier Ltd, USA, 2012, pp. 304-310.

[8] King, M. L., Takeguchi, K., Barry, S. E., Rehfeldt, R. A., Boyer, V. E., and Mathews, T. L., "Evaluation of the iPad in the acquisition of requesting skills for children with autism spectrum disorder", Research in Autism Spectrum Disorders, Elsevier Ltd, USA, 2014, pp. 1107-1120.

[9] Lorah, E. R., Crouser, J., Gilroy, S. P., Tincani, M., \& Hantula, D., "Within Stimulus prompting to teach symbol discrimination using an iPad® speech generating device", Journal of Developmental and Physical Disabilities, Springer New York LLC, USA, 2014, pp. 335-346.
[10] Murdock, L. C., Ganz, J., \& Crittendon, J., "Use of an iPad play story to increase play dialogue of preschoolers with autism spectrum disorders", Journal of autism and developmental disorders, Springer New York LLC, USA, 2013, pp. 2174-2189.

[11] Neely, L., Rispoli, M., Camargo, S., Davis, H., \& Boles, M., "The effect of instructional use of an $\mathrm{iPad} \circledast$ on challenging behavior and academic engagement for two students with autism", Research in Autism Spectrum Disorders, Elsevier Ltd, USA, 2013, pp. 509-516.

[12] Ogle, L. \& Alant, E., "Peer-mediated interventions to promote social communication of elementary school-aged children with autism: A systematic review", Journal of Speech, Language, Hearing Association of Taiwan, Taiwan, 2014, pp. 1533.

[13] O’Malley, P., Lewis, M. E. B., Donehower, C., \& Stone, D., "Effectiveness of using iPads to increase academic task completion by students with autism", Universal Journal of Educational Research, Horizon Research Publishing, USA, 2014, pp. 90-97.

[14] Sigafoos, J., Lancioni, G. E., O’Reilly, M. F., Achmadi, D., Stevens, M., Roche, L., ... \& Green, V. A., "Teaching two boys with autism spectrum disorders to request the continuation of toy play using an iPad®-based speech-generating device", Research in Autism Spectrum Disorders, Elsevier Ltd, USA, 2013, pp. 923-930.

[15] Spooner, F., Ahlgrim-Delzell, L., Kemp-Inman, A., and Wood, L. A., "Using an iPad2® With Systematic Instruction to Teach Shared Stories for Elementary- Aged Students With Autism", Research \& Practice For Persons With Severe Disabilities, Sage Publications, United Kingdom of Great Britain \& Northern Ireland, 2014, pp. 30-46.

[16] van der Meer, L., Achmadi, D., Cooijmans, M., Didden, R., Lancioni, G. E., O'Reilly, M. F., ... \& Sigafoos, J., "An iPad-Based Intervention for Teaching Picture and Word Matching to a Student with ASD and Severe Communication Impairment", Journal of Developmental and Physical Disabilities, Springer New York LLC, USA, 2015, pp. 67-78.

[17] Waddington, H., Sigafoos, J., Lancioni, G. E., O'Reilly, M. F., van der Meer, L., Carnett, A., ... \& Marschik, P. B. (2014). "Three children with autism spectrum disorder learn to perform a three-step communication sequence using an iPad®-based speech-generating device", International Journal of Developmental Neuroscience, Pergamon-Elsevier Science LTD, United Kingdom, 2014, pp. 59-67.

[18] Weng, P., \& Bouck, E., "Using video prompting via iPads to teach price comparison to adolescents 
with autism", Research in Autism Spectrum

Disorders, Elsevier Ltd, USA, 2014, pp. 1405-1415.

[19] White, S. W., Keonig, K., and Scahill, L. "Social Skills Development in Children with Autism Spectrum Disorders: A review of the Intervention Research", Journal of autism and developmental disorders, Springer, USA, 2007, pp. 1858-1868.

[20] Xin, J. F., \& Leonard, D. A., "Using iPads to Teach Communication Skills of Students with Autism", Journal of autism and developmental disorders, Springer New York LLC, USA, 2014, pp. $1-11$. 